\title{
Can the shell of the green-lipped mussel Perna viridis from the west coast of Peninsular Malaysia be a potential biomonitoring material for $\mathrm{Cd}, \mathrm{Pb}$ and $\mathrm{Zn}$ ?
}

\begin{abstract}
The distributions of $\mathrm{Cd}, \mathrm{Pb}$ and $\mathrm{Zn}$ in the total soft tissues and total shells of the green-lipped mussel Perna viridis were studied in field collected samples as well as from laboratory experimental samples. The results showed that $\mathrm{Cd}, \mathrm{Pb}$ and $\mathrm{Zn}$ were readily accumulated in the whole shells. In mussels sampled from 12 locations along the west coast of Peninsular Malaysia, the ratios of the shell metals to the soft tissue metals were different at each sampling site. Nevertheless, the $\mathrm{Cd}$ and $\mathrm{Pb}$ levels in the shells were always higher than those in the soft tissues, while the $\mathrm{Zn}$ level was higher in the soft tissues than in the shells. In comparison with soft tissues, the degrees of variability for $\mathrm{Pb}$ and $\mathrm{Cd}$ concentrations in the shells were lower. The lower degrees of variability and significant $(\mathrm{P}<0.05)$ correlation coefficients of $\mathrm{Cd}$ and $\mathrm{Pb}$ within the shells support the use of the mussel shell as a suitable biomonitoring material for the two metals rather than the soft tissue since this indicated that there is more precision (lower CV) in the determination of metal concentrations in the shell than in the soft tissue. Experimental work showed that the pattern of depuration in the shell was not similar to that of the soft tissue although their patterns of accumulation were similar. This indicated that the depuration of heavy metals in the shell was not affected by the physiological conditions of the mussels. Although $\mathrm{Zn}$ could be regulated by the soft tissue, the incorporated $\mathrm{Cd}, \mathrm{Pb}$ and $\mathrm{Zn}$ remained in the shell matrices. The present results support the use of the total shell of $\mathrm{P}$. viridis as a potential biomonitoring material for long-term contamination of $\mathrm{Cd}, \mathrm{Pb}$ and $\mathrm{Zn}$.
\end{abstract}

Keyword: Perna viridis; Heavy metals; Soft tissue; Shell; Biomonitoring material; Peninsular Malaysia 